\title{
ENTERPRISE ARCHITECTURE PLANNING MENGGUNAKAN TOGAF ADM PADA INDUSTRI RETAIL
}

\author{
Johanes Fernandes Andry ${ }^{1)}$, Lydia Liliana ${ }^{2)}$, Monica Clara ${ }^{3)}$ \\ ${ }^{1,2,3}$ Sistem Informasi, Universitas Bunda Mulia \\ ${ }^{1,2,3} \mathrm{Jl}$. Lodan Raya No. 2, Jakarta Utara \\ Email: ${ }^{1}$ jandry@bundamulia.ac.id, ${ }^{2}$ lydialiliana6@gmail.com, ${ }^{3}$ monica.clara.2002@gmail.com
}

\begin{abstract}
The use of information technology has become important to assist data processing, especially in the electrical equipment retail industry. Retail industry technology has not been fully utilized, especially in terms of marketing, production, delivery, finance and human resources. Problems that arise, such as long data processing times, miscalculation of financial invoices and many more. To harmonize business processes and information systems, business architecture and information systems are designed using the Open Group Architecture Framework (TOGAF) standard with the Architecture Development Method (ADM) method. The selection of TOGAF ADM aims to explain the architecture of the retail industry more specifically in terms of business, technology and information. This research phase includes preliminary, information technology strategy identification, solution identification, architectural vision and enterprise architecture. This research produces an enterprise architecture blueprint design in the form of proposed applications from the business, information and technology side, which is only limited to design. The implementation of the TOGAF ADM phase can maximize the retail industry's business processes in terms of concepts, techniques, integration between business and information technology and determine the transformation in all business, data, application and technology domains.
\end{abstract}

Keyword: Enterprise Architecture, TOGAF ADM, Retail Industry, Blueprint, Business Architecture

\begin{abstract}
Abstrak
Penggunaan teknologi informasi telah menjadi hal penting untuk membantu pengolahan data, terutama dalam industri retail peralatan elektrik. Teknologi industri retail belum dimanfaatkan secara maksimal, terutama dalam hal pemasaran, produksi, pengiriman, keuangan dan sumber daya manusia. Permasalahan yang muncul, seperti waktu pemrosesan data yang lama, kesalahan perhitungan invoice keuangan dan masih banyak lagi. Untuk menyelaraskan proses bisnis dan sistem informasi, maka dilakukan perancangan arsitektur bisnis dan sistem informasi menggunakan standar The Open Group Architecture Framework (TOGAF) dengan metode Architecture Development Method (ADM). Pemilihan TOGAF ADM bertujuan untuk menjelaskan arsitektur industri retail secara lebih spesifik dari sisi bisnis, teknologi dan informasi. Fase penelitian ini meliputi preliminary, identifikasi strategi teknologi informasi, identifikasi solusi, visi arsitektur dan enterprise architecture. Penelitian ini menghasilkan rancangan blueprint enterprise architecture berupa usulan aplikasi dari sisi bisnis, informasi dan teknologi, yang di mana hanya sebatas pada perancangan saja. Penerapan fase TOGAF ADM dapat memaksimalkan proses bisnis industri retail dari segi konsep, teknik, integrasi antara bisnis dan teknologi informasi serta menentukan transformasi di seluruh domain bisnis, data, aplikasi dan teknologi.
\end{abstract}

Kata Kunci: Enterprise Architecture, TOGAF ADM, Retail Industry, Blueprint, Business Architecture

\section{Pendahuluan}

Penggunaan teknologi informasi saat ini memberikan dampak manfaat yang besar terhadap dunia bisnis dan ekonomi [1-3]. Industri melakukan penerapan teknologi agar mampu beradaptasi dengan perubahan serta bersaing dalam kompetisi [4-6]. Persaingan bisnis telah mencapai tahapan kompetisi yang ketat di mana sistem pengelolaan bisnis secara konvensional tidak lagi memadai [7-8]. Teknologi informasi memiliki potensi untuk mengubah seluruh aspek di dalam industri dan mencapai keselarasan antara strategi bisnis serta strategi teknologi yang efektif dan efisien. Pemanfaatan sistem dan teknologi informasi ini harus selaras dan sesuai dengan tujuan industri karena banyak kasus kegagalan dalam mencapai tujuan yang tidak berdasarkan rencana strategi pemanfaatan teknologi informasi [9-11]. Proses identifikasi perencanaan strategi sistem informasi dimulai dari lingkungan industri yang memuat visi, misi dan tujuan organisasi. Hasil dari perencanaan strategi sistem informasi dan teknologi informasi dapat menjawab permasalahan pemanfaatan sistem informasi dan teknologi informasi suatu industri, salah satunya pada industri retail peralatan listrik.

Industri retail peralatan listrik bergerak dalam bidang penjualan kabel-kabel listrik. Keseluruhan produk 
tersebut dikirimkan kepada pelanggan dari berbagai sektor, seperti bandara, pelabuhan, pertahanan, infrastruktur, minyak, gas, kelautan, transportasi hingga penambangan. Namun, pemanfaatan teknologi informasi pada industri retail peralatan listrik saat ini belum dilakukan secara maksimal dalam beberapa bidang, sehingga menghambat proses jual beli alat listrik kepada pelanggan dari berbagai sektor. Kendala-kendala tersebut, seperti waktu tunggu yang lama dalam memproses data penjualan, penanganan error yang tidak terselesaikan berbulan-bulan, pengiriman barang yang lama dan tidak terlacak serta kesalahan perhitungan invoice keuangan yang menyebabkan munculnya penunggakan tagihan. Selain permasalahan di beberapa aspek bisnis, tidak adanya dokumentasi mengenai sumber daya manusia juga menjadi salah satu penyebab beberapa aspek bisnis di industri retail tidak berjalan dengan lancar. Permasalahan yang dihadapi dalam beberapa bidang bisnis membuat industri retail memerlukan perencanaan arsitektur bisnis dan arsitektur sistem informasi dengan tujuan mencapai visi dan misi industri. Oleh karena itu, untuk mencapai visi industri retail yang baik secara finansial maupun operasional, perlu dilakukan penerapan enterprise architecture.

Dumitriu and Popescu menyatakan bahwa enterprise architecture merupakan struktur transformasi aktual industri untuk menyelaraskan bisnis dan teknologi di masa depan nanti [12]. Tujuan enterprise architecture adalah untuk mengoptimalkan seluruh aspek perusahaan terhadap perubahan dan mendukung penyampaian strategi bisnis organisasi [13-15]. Kerangka kerja arsitektur enterprise dapat membantu meningkatkan strategi bisnis organisasi, memiliki informasi dan proses bisnis yang konsisten serta menekan risiko dan biaya penerapan teknologi [16-17]. Salah satu framework atau standar untuk mengembangkan enterprise architecture yang dapat digunakan di industri retail adalah TOGAF. TOGAF memiliki metode dalam membuat, mengelola dan mengimplementasikan arsitektur enterprise pada industri yang dikenal dengan Architecture Development Method (ADM). TOGAF ADM dapat digunakan sebagai panduan atau alat untuk merencanakan, merancang, mengembangkan dan mengimplementasikan arsitektur bisnis dan arsitektur sistem informasi untuk industri [18-20].

Implementasi arsitektur bisnis dan arsitektur sistem informasi pada industri retail menggunakan TOGAF ADM akan menghasilkan rancangan blueprint enterprise architecture yang mampu memperbaiki bisnis, informasi maupun teknologi. Rancangan blueprint akan memberikan panduan prinsip dan tata letak bisnis terbaru untuk meningkatkan kinerja industri retail secara keseluruhan. Oleh karena itu, penelitian ini memanfaatkan penggunaan TOGAF ADM dalam merancang arsitektur enterprise industri retail peralatan elektrik untuk menyelesaikan permasalahan aspek bisnis yang ada, terutama dalam dalam hal pemasaran, produksi, pengiriman, keuangan dan sumber daya manusia. Hasil akhir penelitian ini akan merumuskan pedoman dalam menerapkan prosedur industri retail terbaru, seperti prinsip enterprise architecture, strategi teknologi informasi, solusi sistem informasi, visi dan misi industri yang diharapkan dapat bermanfaat dalam meningkatkan kinerja industri retail menggunakan bantuan sistem informasi dan teknologi informasi.

\section{Metode}

Perancangan enterprise architecture yang difokuskan pada arsitektur bisnis dan arsitektur sistem informasi. TOGAF ADM diharapkan mampu memberikan gambaran umum mengenai bagaimana teknologi diterapkan untuk mendukung strategi bisnis industri retail [21]. Tahapan penelitian dijelaskan pada Gambar 1 [2223].

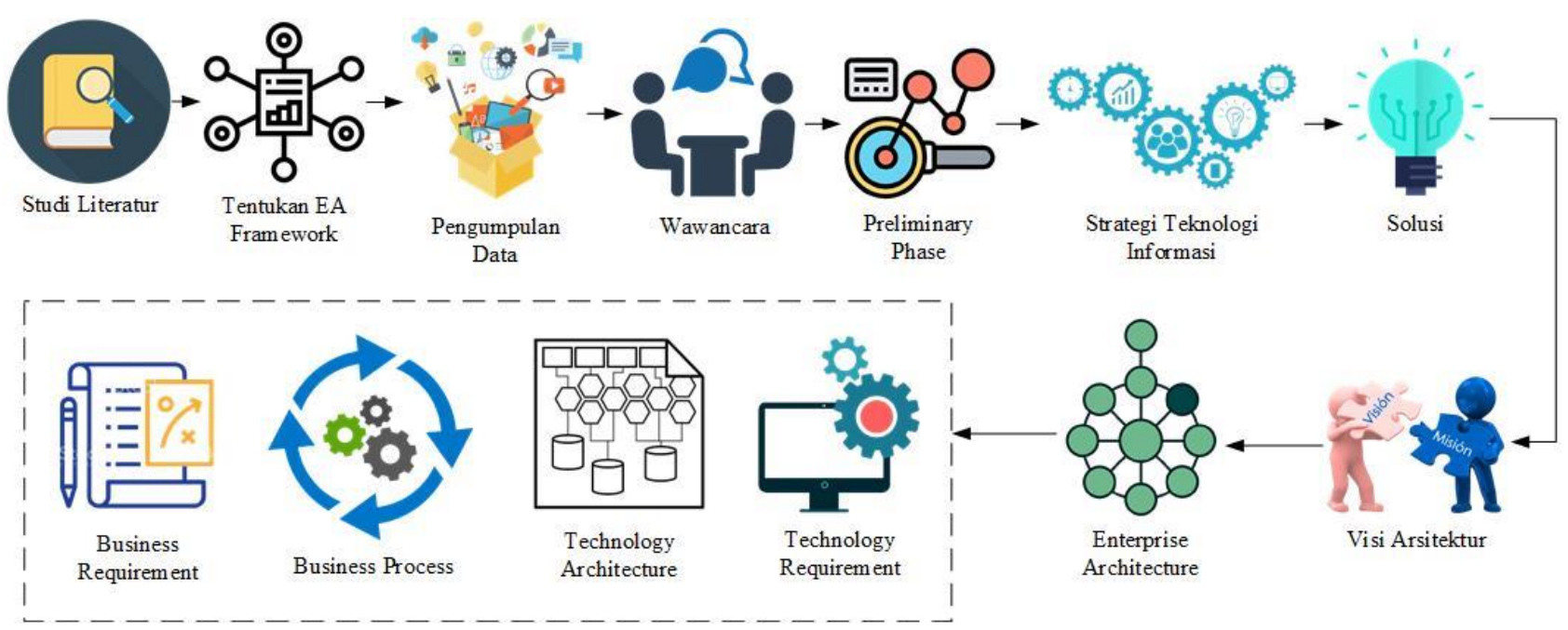

Gambar 1. Tahapan Penelitian [24-25].

Gambar 1 menunjukkan penelitian dimulai dari menganalisis strategi dan tujuan bisnis melalui kajian aspek bisnis, yaitu visi, misi, tujuan bisnis dan bisnis yang dijalankan. Enterprise architecture framework yang digunakan adalah TOGAF ADM. Pengumpulan data dilakukan melalui studi dokumen dan wawancara 
manajemen. Perancangan dimulai dari merumuskan prinsip-prinsip arsitektur industri retail yang akan menghasilkan strategi teknologi informasi. Strategi tersebut tentunya akan memunculkan solusi baru dalam sistem informasi untuk memperbaiki visi dan misi industri retail. Keseluruhan pengumpulan requirement dapat dimodelkan dalam bentuk enterprise architecture yang dapat memperbaiki serta meningkatkan beberapa hal, yaitu business requirement, business process, technology architecture dan technology requirement [26-27].

\section{Hasil dan Analisis}

Analisis dan perancangan yang dilakukan meliputi preliminary phase, architecture vision phase, business architecture phase dan technology architecture phase.

\section{Preliminary Phase}

Prinsip-prinsip perencanaan arsitektur enterprise memiliki sifat yang umum untuk digunakan dalam tahapan awal pengembangan perencanaan arsitektur enterprise yang menggambarkan karateristik serta tujuan dari arsitektur sistem informasi dan teknologi informasi yang akan dikembangkan seperti pada Tabel 1 .

Tabel 1. Katalog Prinsip

\begin{tabular}{|c|c|c|}
\hline No & Prinsip & Tujuan \\
\hline 1 & Bisnis & $\begin{array}{l}\text { Hubungan proses bisnis, } \\
\text { infratruktur dan sistem } \\
\text { Adaptasi proses bisnis terhadap } \\
\text { perubahan } \\
\text { Performa kerja } \\
\text { Strategi dan tujuan bisnis } \\
\text { Mempersingkat waktu }\end{array}$ \\
\hline 2 & Data & $\begin{array}{l}\text { Keamanan data } \\
\text { Pengelolaan data } \\
\text { Ketersediaan data }\end{array}$ \\
\hline 3 & Aplikasi & $\begin{array}{l}\text { Kemampuan berbagi data dan } \\
\text { sumber daya } \\
\text { Respon perubahan tren }\end{array}$ \\
\hline 4 & Teknologi & $\begin{array}{l}\text { Mencegah data tidak kompatibel } \\
\text { Meminimalkan keragaman } \\
\text { software }\end{array}$ \\
\hline
\end{tabular}

Tabel 1 menjabarkan katalog prinsip perancangan yang menggambarkan penggunaan prinsip-prinsip dan tujuan dari setiap prinsip-prinsip arsitektur industri retail. Katalog prinsip ini akan digunakan dalam proses perancangan arsitektur industri retail. Proses pendefinisian kebijakan sistem informasi dan teknologi informasi ini akan sangat berpengaruh terhadap keseluruhan perencanaan arsitektur enterprise.

\section{Identifikasi Strategi Teknologi Informasi (TI)}

Analisis strategi teknologi informasi dilakukan untuk mengatasi permasalahan-permasalahan yang ada pada setiap aktivitas industri retail seperti pada Tabel 2 .
Tabel 2. Identifikasi Strategi TI

\begin{tabular}{|c|c|c|}
\hline No & Masalah & Strategi TI \\
\hline 1 & $\begin{array}{c}\text { Informasi } \\
\text { Perusahaan }\end{array}$ & $\begin{array}{l}\text { Fasilitas media promosi } \\
\text { Informasi produk } \\
\text { Komplain pengaduan produk }\end{array}$ \\
\hline 2 & $\begin{array}{l}\text { Penjualan dan } \\
\text { Pembelian }\end{array}$ & $\begin{array}{l}\text { Penjualan barang } \\
\text { Ketersediaan produk } \\
\text { Negosiasi harga }\end{array}$ \\
\hline 3 & Keuangan & $\begin{array}{l}\text { Pelaporan keuangan } \\
\text { Pembayaran tagihan } \\
\text { Penggajian }\end{array}$ \\
\hline 4 & $\begin{array}{l}\text { Sumber Daya } \\
\text { Manusia }\end{array}$ & $\begin{array}{l}\text { Absensi dan cuti } \\
\text { Besaran gaji }\end{array}$ \\
\hline 5 & Stok & $\begin{array}{l}\text { Barang masuk dan keluar } \\
\text { Barang retur }\end{array}$ \\
\hline 6 & Pengiriman & Lacak pengantaran \\
\hline 7 & Event & $\begin{array}{l}\text { Reminder pembayaran } \\
\text { cicilan } \\
\text { Reminder kegiatan }\end{array}$ \\
\hline
\end{tabular}

Tabel 2 menunjukkan proses peninjauan yang dilakukan berdasarkan sudut pandang proses kerja. Sasaran perbaikan yang ingin dicapai adalah terfokus agar alur kerja industri retail menjadi lebih baik.

\section{Identifikasi Solusi}

Setelah melakukan analisis strategi TI, dilakukan identifikasi pola-pola solusi dari strategi yang telah dirumuskan pada Tabel 3.

Tabel 3. Identifikasi Pola Solusi

\begin{tabular}{|c|c|c|}
\hline No & Pola Solusi & Solusi Sistem \\
\hline 1 & Informasi Industri & $\begin{array}{l}\text { Company } \\
\text { Website }\end{array}$ \\
\hline 2 & Penjualan Produk & Aplikasi Penjualan \\
\hline 3 & Pembelian Produk & E-Procurement \\
\hline 4 & Keuangan & Aplikasi Finance \\
\hline 5 & Sumber Daya Manusia & $\begin{array}{l}\text { Human Resource } \\
\text { Information System }\end{array}$ \\
\hline 6 & Stok & Aplikasi Inventory \\
\hline 7 & Pengiriman & Aplikasi Tracking \\
\hline 8 & Event & $\begin{array}{l}\text { Aplikasi Event } \\
\text { Reminder List }\end{array}$ \\
\hline
\end{tabular}

Tabel 3 menjabarkan solusi sistem yang berfokus pada pengembangan aplikasi untuk mendukung proses kerja dan aktivitas industri retail. Solusi sistem ditinjau berdasarkan sudut pandang strategi IT.

\section{Architecture Vision Phase}

Industri retail mempunyai visi untuk Memanfaatkan jangkauan global dan kehadiran lokal untuk menyelesaikan proyek klien dengan kemampuan terbaik. Untuk mewujudkan visi tersebut, industri retail mempunyai tiga misi utama: 
1. Memastikan pasokan yang andal dan harga terbaik untuk klien dengan pengalaman gabungan di seluruh manajemen situs dan kemampuan listrik.

2. Memberikan solusi yang terintegrasi untuk fasilitas global dan sistem operasi dengan menyasar sektorsektor industri dan infrastruktur.

3. Meningkatkan profitabilitas klien dengan membangun semua manajemen material mulai dari proyek hingga penyelesaian.

Maka dari itu, dilakukan pemetaan proses bisnis yang berjalan dalam bentuk value chain.

1. Primary Activity

- Inbound Logistic. Proses pemesanan produk, pembelian produk ke supplier, pembelian ATK, PC serta pembelian barang-barang pendukung lainnya.

- Operation. Proses pencarian customer, purchase order, pemeriksaan kualitas produk, pengiriman dan pemberian surat jalan.

- Outbound Logistic. Proses pengiriman barang ke customer dan memberikan surat jalan untuk ditandatangan.

- Marketing dan Sales. Menggunakan sistem koneksi dan kepercayaan serta pemasaran secara langsung.

- Services. Garansi barang sampai dengan selamat, penukaran produk, standar keamanan, produk dapat disesuaikan dengan kebutuhan customer.

2. Aktivitas Pendukung

- Firm Infrastructure. Manajemen keuangan, sumber daya, informasi, gudang penyimpanan produk, lahan parkir serta gedung kantor.

- Human Resource Management. Perekrutan, seleksi, gaji, reward dan sanksi bagi para pekerjanya.

- Technology Development. Pembuatan surat, invoice, pembukuan, penyebaran informasi melalui email dan phone.

- Procurement. Alat tulis kantor, komputer, mobil barang serta bahan bakar.

\section{Enterprise Architecture}

Perancangan enterprise architecture memperhatikan keselarasan antara teknologi informasi dan kebutuhan bisnis yang bertujuan untuk mengurangi kesenjangan sistem. Berikut gambaran bisnis yang diinginkan oleh pengguna:

- Pembuatan website yang memberikan informasi umum dan produk perusahaan, serta dapat menangani komplain.

- Pembuatan aplikasi penjualan barang yang dapat mengecek ketersediaan produk dan negosiasi.

- Pembuatan aplikasi e-procurement untuk membantu pembelian barang ke supplier serta pengecekan terhadap katalog produk baru.

- Pembuatan aplikasi finance untuk membantu pelaporan keuangan serta penggajian.

- Pembuatan aplikasi HRIS untuk membantu proses absensi dan pengajuan cuti.

- Pembuatan aplikasi inventory untuk membantu pengelolaan stok barang.
- Pembuatan aplikasi tracking untuk membantu pemantauan terhadap pesanan customer.

- Pembuatan aplikasi event reminder list sebagai pengingat pembayaran cicilan hutang dan event.

Hasil dari perancangan enterprise architecture ini menghasilkan gambaran business requirement, business process, technology architecture dan technology requirement yang akan diterapkan pada industri retail.

a) Business Requirement

Setiap layanan bisnis mempunyai beberapa proses bisnis dan sub proses bisnis. Terakhir, setiap proses bisnis akan mempunyai beberapa fungsi bisnis dan sub fungsi bisnis. Sub fungsi bisnis merupakan unit aktivitas terkecil. Pemetaan layanan bisnis, proses bisnis dan fungsi bisnis digambarkan dalam Tabel 4.

Tabel 4. Business Requirement

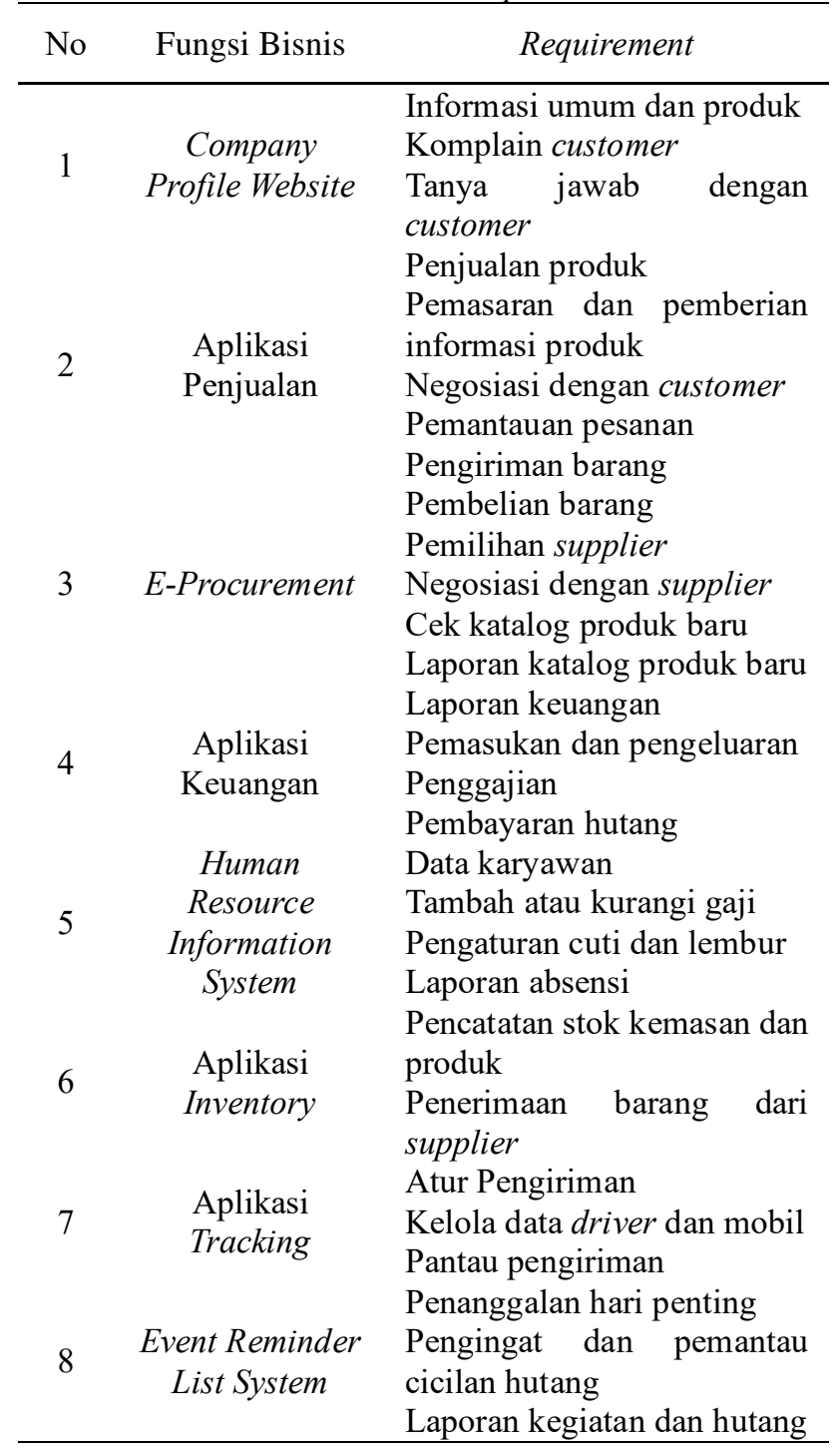

Table 4 menjelaskan gambaran business architecture requirement yang akan diterapkan pada industri retail berdasarkan tahapan TOGAF ADM. Terdapat 8 rancangan fungsi bisnis yang dibutuhkan oleh industri retail, yaitu company profile website, aplikasi penjualan, aplikasi eprocurement, aplikasi finance, human resource 
information system, aplikasi inventory, aplikasi tracking dan aplikasi event reminder list.

\section{b) Business Process}

Arsitektur TOGAF-ADM yang akan diterapkan pada organisasi ini diawali dengan mempersiapkan kebutuhan arsitektur dengan melakukan kegiatan inisialisasi yang dibutuhkan untuk memenuhi arah bisnis dari arsitektur enterprise yang akan dikembangkan. Tahapan yang akan dipengaruhi oleh implementasi arsitektur TOGAF-ADM ini digambarkan pada Gambar 2.

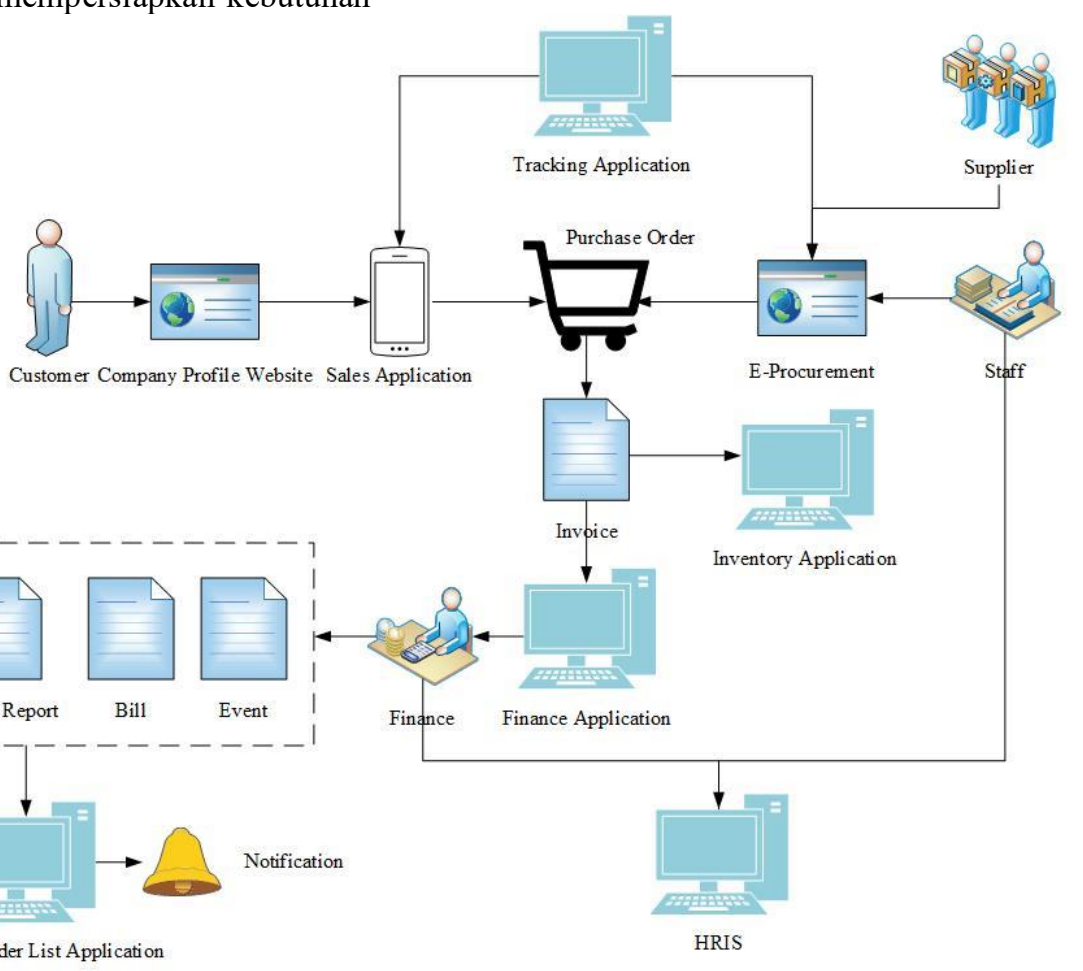

Gambar 2. Alur Proses Bisnis.

Gambar 2 menunjukkan alur proses bisnis yang dimulai dari customer yang mengakses company profile website dan aplikasi penjualan. Secara bersamaan, staff industri dan supplier mengakses e-procurement system. Aplikasi penjualan dan e-procurement system terhubung dengan aplikasi tracking. Customer dan staff melakukan purchase order yang menghasilkan invoice untuk diakses di aplikasi finance. Invoice ini juga menjadi dasar pengurangan stok di aplikasi inventory. Finance akan mengeluarkan financial statement, bill, payroll report dan jadwal pembayaran. Aplikasi finance terintegrasi dengan aplikasi event reminder list untuk memunculkan notifikasi event dan pembayaran hutang. Terkait sumber daya manusia, penggunaan human resource information system diperlukan industri untuk mengelola data karyawan, pengajuan cuti dan absensi.

Setelah dilakukan pemetaan alur proses bisnis, didapatkan gap untuk mendefinisikan kesenjangan antara arsitektur bisnis yang ada saat ini dengan arsitektur bisnis di masa depan. Pada arsitektur bisnis saat ini, kegiatan teknologi informasi yang berada di industri retail masih terbatas dalam hal membantu proses bisnis, pemahaman karyawan yang kurang mengenai penggunaan teknologi informasi dan tidak terdapatnya divisi teknologi informasi di industri retail. Untuk arsitektur bisnis di masa mendatang, kegiatan di bidang teknologi informasi pada industri retail dapat dibantu dengan menggunakan aplikasi. Selain itu, keseluruhan karyawan di industri retail dapat memahami cara penggunaan teknologi informasi dengan diberikan pelatihan terlebih dahulu. Untuk meningkatkan struktur pengembangan teknologi informasi di industri retail, maka dilakukan penambahan keanggotaan struktur teknologi informasi yang lebih spesifik dengan tugas masing-masing.

\section{c) Technology Architecture}

Technology architecture menggambarkan platform teknologi yang mendukung operasi arsitektur sistem informasi. Diagram ini mencakup semua platform infrastruktur dan memberikan gambaran umum mengenai platform teknologi perusahaan. Technology architecture digambarkan dalam platform decomposition diagram menjelaskan sistem usulan secara menyeluruh yang terdiri dari 5 level, yaitu interface, presentation, network, application dan database. Gambar 3 menunjukkan platform decomposition diagram dari industri retail yang menggambarkan sistem secara menyeluruh. Interface dapat menggunakan internet maupun LAN atau dapat menggunakan web browser yang terhubung menggunakan internet pada aplikasi yang berbasis web. Pengembangan aplikasi mobile menggunakan Android Studio dengan bahasa pemrograman Java Kotlin. Untuk pengembangan aplikasi website, menggunakan bahasa pemrograman PHP (Hypertext Preprocessor), sedangkan pada aplikasi desktop menggunakan bahasa pemrograman Visual Basic. 


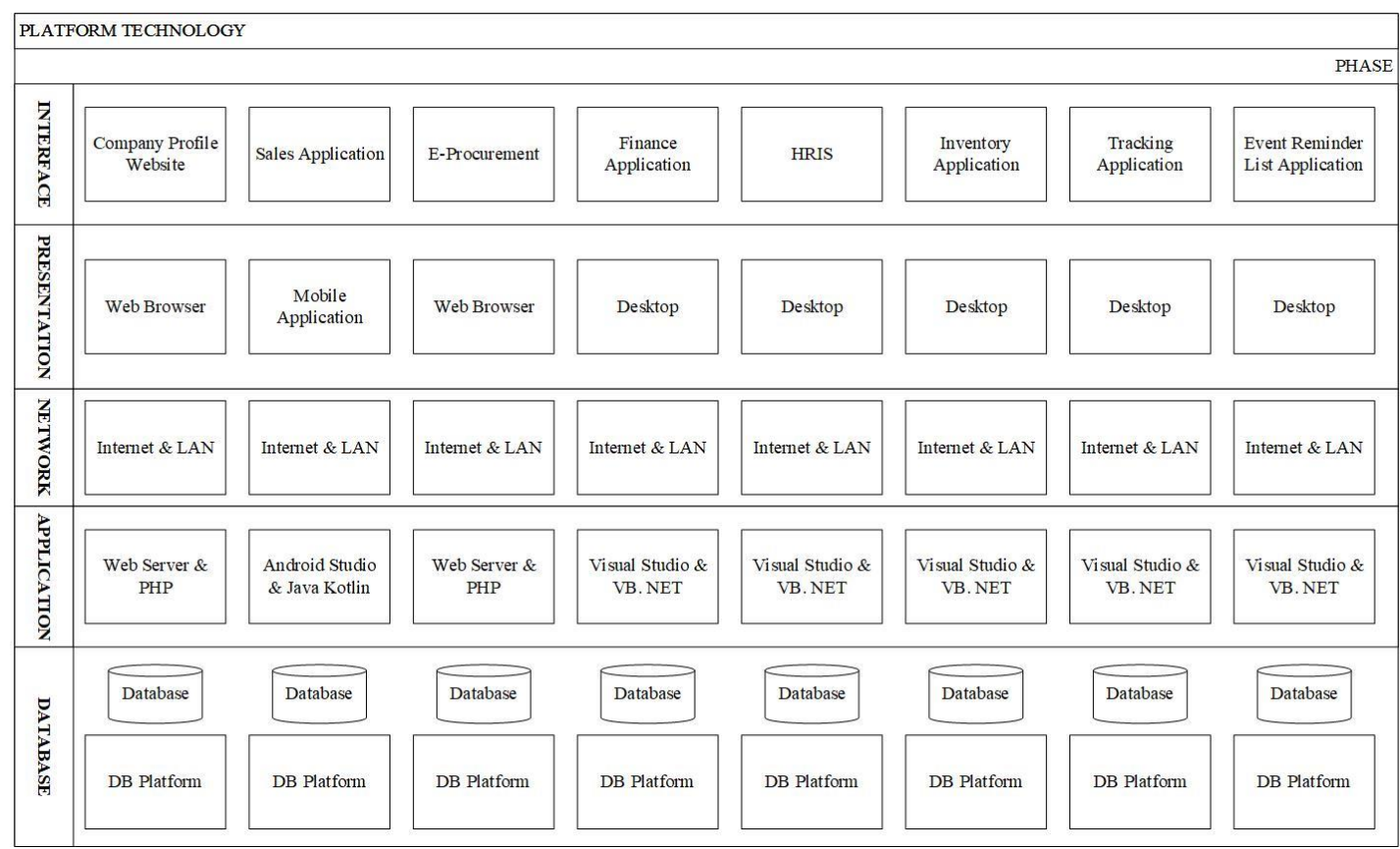

Gambar 3. Platform Decomposition Diagram.

\section{d) Technology Requirement}

Fase technology requirement diperlukan untuk memetakan kebutuhan apa saja yang harus dipenuhi dalam melakukan perancangan arsitektur teknologi yang terdapat pada Tabel 5 .

Tabel 5. Technology Requirement

\begin{tabular}{lll}
\hline No & \multicolumn{3}{c}{ Requirement } \\
\hline 1 & $\begin{array}{l}\text { Laporan digital produk yang dipesan serta } \\
\text { bidding harga secara live. }\end{array}$ \\
\hline
\end{tabular}

2 produk baru, menerima pelaporan, katalog baru serta perhitungan keuangan secara otomatis.

3 Kemampuan teknologi mengurangi stok secara otomatis dan pembuatan surat jalan secara digital.

4 Teknologi otomatis dalam mencetak laporan pengiriman dan penerimaan produk.

5 Kemampuan teknologi menawarkan produk baru ke customer serta desain produk yang menarik.

6 Konsistensi harga, kualitas, kemasan dan infrastruktur yang ada.

Pelaporan digital terhadap data sumber daya

7 manusia, meliputi cuti, reward, sanksi dan penggajian.

Integrasi sistem satu sama lain antara proses

8 pemesanan produk dari customer serta pembelian produk ke supplier.

9 Kemampuan pengaturan penggunaan data terhadap procurement yang dikeluarkan industri.

Kemampuan teknologi dalam memberikan

10 penjadwalan rapat dan mengingatkan pembayaran cicilan.
Tabel 5 menjabarkan terdapat beberapa kebutuhan untuk melakukan perancangan teknologi. Selanjutnya, dijabarkan urutan implementasi aplikasi, berdasarkan perspektif organisasi dari sisi operasional dan sisi manajemen. Terdapat 2 pembagian di dalam perspektif operasional, yaitu front office system dan back office system. Biasanya, aplikasi yang berada di dalam perspektif operasional akan lebih diutamakan untuk pengimplementasian pada urutan awal karena aplikasi tersebut berkaitan langsung dengan berjalannya suatu aktivitas serta aplikasi tersebut juga dapat menentukan tingkat kinerja dari suatu aktivitas.

1. Perspektif Operasional

Aplikasi dalam perspektif operasional dibagi menjadi dua bagian, yaitu kelompok aplikasi yang orientasi fungsinya langsung memberikan pelayanan kepada pengguna di luar organisasi (front office system) dan kelompok aplikasi yang orientasi fungsinya lebih ditujukan untuk membantu dalam aktivitas administrasi kepada pengguna di dalam organisasi (back office system). Pada front office system, terdapat company profile website dan aplikasi penjualan. Kemudian, pada back office system terdapat e-procurement, aplikasi inventory dan aplikasi tracking.

2. Perspektif Manajemen

Aplikasi yang dikelompokkan ke dalam perspektif manajemen berarti aplikasi tersebut berfungsi untuk melakukan pengorganisasian, pencatatan dan pengawasan terhadap para anggota organisasi serta terhadap penggunaan sumber daya organisasi. Aplikasi yang termasuk dalam perspektif manajemen adalah aplikasi finance, human resource information system dan aplikasi event reminder list. 


\section{Kesimpulan}

Penerapan enterprise architecture di industri retail mampu menjelaskan rencana untuk membangun sistem, termasuk parameter informasi, fungsionalitas, lokasi dan kinerja. Penggunaan TOGAF ADM berhasil memperoleh struktur dan strategi yang baik untuk diterapkan ke industri retail. Beberapa hasil yang diperoleh dari enterprise architecture ini, berupa gambaran business requirement, business process, technology architecture dan technology requirement. Penggambaran arsitektur bisnis dalam bentuk requirement perbaikan serta restrukturisasi alur proses bisnis yang berjalan saat ini. Kemudian, penggambaran arsitektur sistem informasi terlihat dari pendefinisian technology requirement yang diinginkan pengguna serta menggambarkan technology architecture dalam bentuk platform decomposition diagram. Hasil ini mampu meningkatkan fleksibilitas restrukturisasi bisnis, efisiensi operasi teknologi informasi serta memunculkan prediksi terhadap dampak perubahan di masa depan. Untuk area penelitian di masa mendatang, dapat dilakukan penerapan infrastruktur yang menunjukkan keperluan investasi perangkat keras dan perangkat lunak. Hal ini didasarkan pada penggunaan framework TOGAF yang dapat dikembangkan lebih mendetail untuk memperoleh metode implementasi strategi teknologi informasi, indentifikasi permasalahan strategis perusahaan serta menyusun arsitektur teknologi informasi yang jauh lebih matang.

\section{Daftar Pustaka}

[1] C. M. Firmansyah and Y. Bandung, "Designing an Enterprise Architecture Government Organization Based on TOGAF ADM and SONA," Int. Conf. Inf. Technol. Syst. Innov., pp. 1-6, 2016, doi: 10.1109/ICITSI.2017.8267915.

[2] A. K. Darmawan, D. O. Siahaan, T. D. Susanto, Hoiriyah, B. A. Umam, and A. Hermanto, "A Model Of Smart Regency Framework Using MetaEthnography Approach And TOGAF ADM 9.1," J. Phys. Conf. Ser., vol. 1569, no. 2, pp. 1-6, 2020, doi: 10.1088/1742-6596/1569/2/022005.

[3] R. Anderson and J. F. Andry, "Perancangan Enterprise Arsitektur Menggunakan Framework TOGAF," Ultim. InfoSys J. Ilmu Sist. Inf., vol. 12, no. 1, pp. 58-66, 2021, doi: 10.31937/si.v12i1.1801.

[4] K. Schwertner, "Digital Transformation Of Business," Trakia J. Sci., vol. 15, no. Suppl.1, pp. 388-393, 2017, doi: 10.15547/tjs.2017.s.01.065.

[5] N. N. Qomariyah and A. Priandoyo, "Industry 4.0 Strategic Alignment Framework: Multilevel Perspective Of Digital Transition In Indonesia," 2020 Int. Conf. Smart Technol. Appl. Empower. Ind. IoT by Implement. Green Technol. Sustain. Dev., pp. $1-6$, 2020 ,

doi: 10.1109/ICoSTA48221.2020.1570611033.

[6] Suryadi and J. F. Andry, "Perancangan Enterprise Architecture Mengunakan TOGAF Architecture Development Method (Studi Kasus: Yakuza Gym
Jakarta Barat)," Semin. Nas. TEKNOKA, vol. 2, pp. 129-134, 2017, [Online]. Available: https://journal.uhamka.ac.id/index.php/teknoka/arti cle/view/748.

[7] E. M. M. Nasef and N. Azaliah, "Enterprise Architecture 'As-Is' Analysis for Competitive Advantage," Int. J. Adv. Comput. Sci. Appl., vol. 11, no. $7, \quad$ pp. 102-107, 2020, doi: 10.14569/ijacsa.2020.0110714.

[8] B. Qeliaja, B. Abazi, and E. Hajrizi, "Enterprise Technology Architecture Solution For eHealth System And Implementation Strategy," IFACPapersOnLine, vol. 52, no. 25, pp. 370-375, 2019, doi: 10.1016/j.ifacol.2019.12.554.

[9] S. R. Mirsalari and M. Ranjbarfard, "A Model For Evaluation Of Enterprise Architecture Quality," Eval. Program Plann., vol. 83, no. August, pp. 1-12, 2020, doi: 10.1016/j.evalprogplan.2020.101853.

[10] F. E. Gunawan, J. F. Andry, H. Tannady, and R. Meylovsky, "Designing Enterprise Architecture Using Togaf Framework In Meteorological, Climatological, And Geophysical Agency," J. Theor. Appl. Inf. Technol., vol. 97, no. 20, pp. 2376-2385, 2019.

[11] I. Ibrahim, "Perancangan Arsitektur Teknologi Informasi dan Komunikasi Dengan Menggunakan Kerangka Kerja Togaf Adm Pada PT Timah," Barometer, vol. 1, no. 1, pp. 34-43, 2016, doi: 10.35261/BAROMETER.V1I1.363.

[12] D. Dumitriu and M. A. M. Popescu, "Enterprise Architecture Framework Design In IT Management," Procedia Manuf., vol. 46, pp. 932940, 2020, doi: 10.1016/j.promfg.2020.05.011.

[13] E. Kornyshova and J. Barrios, "Industry 4.0 Impact Propagation On Enterprise Architecture Models," Procedia Comput. Sci., vol. 176, pp. 2497-2506, 2020, doi: 10.1016/j.procs.2020.09.326.

[14] Q. Zhi and Z. Zhou, "Empirically Modeling Enterprise Architecture Using Archimate," Comput. Syst. Sci. Eng., vol. 40, no. 1, pp. 357-374, 2022, doi: 10.32604/CSSE.2022.018759.

[15] J.- Leonidas and J. F. Andry, "Perancangan Enterprise Architecture Pada PT. Gadingputra Samudra Menggunakan Framework TOGAF ADM," J. Teknoinfo, vol. 14, no. 2, pp. 71-80, 2020, doi: $10.33365 /$ jti.v14i2.642.

[16] M. Berg, R. Slot, M. Steenbergen, P. Faasse, and H. van Vliet, "How Enterprise Architecture Improves The Quality Of IT Investment Decisions," J. Syst. Softw., vol. 152, pp. 134-150, 2019, doi: 10.1016/j.jss.2019.02.053.

[17] R. P. Castillo, F. Ruiz, and M. Piattini, “A DecisionMaking Support System For Enterprise Architecture Modelling," Decis. Support Syst., vol. 131, no. January, pp. 1-18, 2020, doi: 10.1016/j.dss.2020.113249.

[18] H. Tsuchiya, S. Yamamoto, Y. Murakami, T. Yanagisawa, N. Kobayashi, and J. Wan, "Two-Stage Third-Party Review Proposal Using The Enterprise Architecture In Software Development," Procedia 
Comput. Sci., vol. 126, pp. 1187-1196, 2018, doi: 10.1016/j.procS.2018.08.059.

[19] V. Goepp and M. Petit, "Insight From A Comparison Of TOGAF ADM And SAM Alignment Processes," IFAC-PapersOnLine, vol. 50, no. 1, pp. 1170711712, 2017, doi: 10.1016/j.ifacol.2017.08.1693.

[20] B. Wicaksono and J. F. Andry, "Perancangan Arsitektur Bisnis Pada Industri Aluminium Foil Menggunakan TOGAF," IT J. Res. Dev., vol. 5, no. 1, pp. 98-108, 2020, doi: 10.25299/itjrd.2020.vol5(1).4755.

[21] D. Goncalves, L. Ferreira, and N. Campos, "Enterprise Architecture For High Flexible And Agile Company In Automotive Industry," Procedia Comput. Sci., vol. 181, no. 2019, pp. 1077-1082, 2021, doi: 10.1016/j.procs.2021.01.303.

[22] S. T. N. Andi, N. F. A. Amalia, and M. Lubis, "IT Roadmap to Improve Business Strategy using TOGAF ADM: A Case Study of GovernmentOwned Electricity Company," J. Phys. Conf. Ser., vol. 1361, no. 1, 2019, doi: 10.1088/17426596/1361/1/012017.

[23] M. I. Mutakin, "Designing Enterprise Architecture for Distributor of Consumer Product Using TOGAF ADM," IOP Conf. Ser. Mater. Sci. Eng., vol. 879, no.
1, pp. 1-6, 2020, doi: 10.1088/1757899X/879/1/012063.

[24] A. A. GEBAYEW, Chernet; ARMAN, "Modify TOGAF ADM for Government Enterprise Architecture," 2019 IEEE 5th Int. Conf. Wirel. Telemat., pp. 1-6, 2019.

[25] W. Sardjono and R. M. Vijayanto, "Designing Of IT Master Plan Based On TOGAF ADM Framework In The Regional Water Utility Company," IOP Conf. Ser. Earth Environ. Sci., vol. 729, no. 1, pp. 1-10, 2021, doi: 10.1088/1755-1315/729/1/012016.

[26] M. A. A. Hakim, D. N. Saputri, and R. R. Warang, "Information Technology Architecture Design to Automate Enterprise Business Process Using TOGAF ADM," Int. J. Mech. Eng. Technol., vol. 10, no. 03, pp. 1525-1234, 2019.

[27] F. Binsar and N. Legowo, "Design of Cloud Computing Outpatient Registration Model Through SMS Messages at Hospitals using TOGAF ADM," Int. J. Recent Technol. Eng., vol. 8, no. 5, pp. 38573865, 2020, doi: 10.35940/ijrte.e4885.018520. 